\title{
An unusual appearance of complicated hydatid cyst: necrotizing pancreatitis
}

\author{
Hasan Ediz Sıkar, M.D., Levent Kaptanoğlu, M.D., Metin Kement, M.D. \\ Department of General Surgery, Kartal Dr. Lütfi Kirdar Training and Research Hospital, İstanbul-Turkey
}

\begin{abstract}
Hydatid acute pancreatitis is a rare condition and always presents as consequence of acute edematous pancreatitis. Intrabiliary rupture of hepatic hydatid cysts and obstruction of papillary orifice with hydatid membrane is possible mechanism. A 49-year-old man was admitted with epigastric and right upper quadrant pain, nausea, and vomiting. Computed tomography scan showed $5 \times 5 \mathrm{~cm} c y s t$ in left hepatic lobe, which had ruptured into the biliary tract and caused necrotizing pancreatitis. Endoscopic retrograde cholangiopancreatography trial failed. Surgical choice was drainage of cyst, insertion of T-Tube, exploration of common bile duct and omentoplasty. No additional necessary surgical intervention was necessary for necrotizing pancreatitis. Clinical and laboratory findings resolved rapidly and there was no recurrent pancreatitis episode during I year of follow-up. Hydatid edematous and necrotizing pancreatitis have similar progress. Recovery is quick and uneventful after elimination of mechanical obstruction of papillary orifice.
\end{abstract}

Keywords: Biliary fistula; echinococcosis; pancreatitis.

\section{INTRODUCTION}

Echinococcosis, also called hydatid disease, hydatidosis or echinococcal disease, is a parasitic illness of tapeworms of the genus Echinococcus. Cysts are most common form of disease appearance, typically in the liver. ${ }^{[1,2]}$ In many cases, lack of symptoms is major obstacle to early diagnosis. Localization and size of cyst play major role in late symptoms, which often include abdominal pain, weight loss, and icterus. Simple cysts may be easily treated with surgery, punctureaspiration-injection-reaspiration procedure, or albendazole. Successful therapy for complicated hydatid liver disease, however, continues to be a challenge. Intrabiliary rupture of cyst is one of the life threatening complications of hydatid disease. Hydatid abscess, cholangitis, obstructive jaundice, and acute pancreatitis are possible clinical presentations. Rupture and obstruction of papillary orifice with hydatid membrane is a

Address for correspondence: Hasan Ediz Sıkar, M.D. Kartal Dr. Lütfi Kırdar Eğitim ve Araştırma Hastanesi, Şemsi Denizer Cad., Cevizli, Kartal, İstanbul, Turkey Tel: +90 216 - 4583000 E-mail: hasan.sikar@me.com

Qucik Response Code

Ulus Travma Acil Cerrahi Derg 2017;23(I):8I-83

doi: $10.5505 /$ tjtes. 2016.26820

Copyright 2017

TJTES potential mechanism for acute pancreatitis. Existing literature reports that hydatid acute pancreatitis presents as edematous pancreatitis. ${ }^{[3,4]}$ Presently described is case of hydatid necrotizing pancreatitis.

\section{CASE REPORT}

A 49-year-old male patient was admitted to clinic with complaints of epigastric and right upper quadrant pain, nausea, and vomiting continuing for 3 days. Fever $\left(39^{\circ} \mathrm{C}\right)$ and jaundice were observed on clinical examination. Laboratory data were: white blood cell count of $17000 / \mathrm{mm}^{3}$, amylase level of $2192 \mathrm{U} / \mathrm{L}$, total bilirubin level of $8.2 \mathrm{mg} / \mathrm{dL}$, direct bilirubin level of $6.9 \mathrm{mg} / \mathrm{dL}$, aspartate aminotransferase level of 312 $\mathrm{U} / \mathrm{L}$, alanine aminotransferase level of $409 \mathrm{U} / \mathrm{L}$, gamma glutamyl transferase level of $318 \mathrm{IU} / \mathrm{L}$, and C-reactive protein level of $93 \mathrm{mg} / \mathrm{L}$. Abdominal computed tomography (CT) scan revealed $5 \times 5 \mathrm{~cm}$ cyst in the left hepatic lobe, which had ruptured into the biliary tract. Dilated main biliary ducts and signs of necrotizing pancreatitis were detected (Fig. Ia, 2a). Endoscopic retrograde cholangiopancreatography trial failed due to difficult cannulation. Patient underwent urgent surgery 24 hours after admission as result of cholangitis. Surgical choice was drainage of the cyst, cholecystectomy, exploration of common bile duct (CBD), and extraction of scolices and hydatid debris from CBD. Isotonic saline solution used to eliminate hydatid debris in biliary tree, and omentoplasty and T-tube drainage of CBD were performed to control bile leakage. In the present case, fine needle aspiration was also 

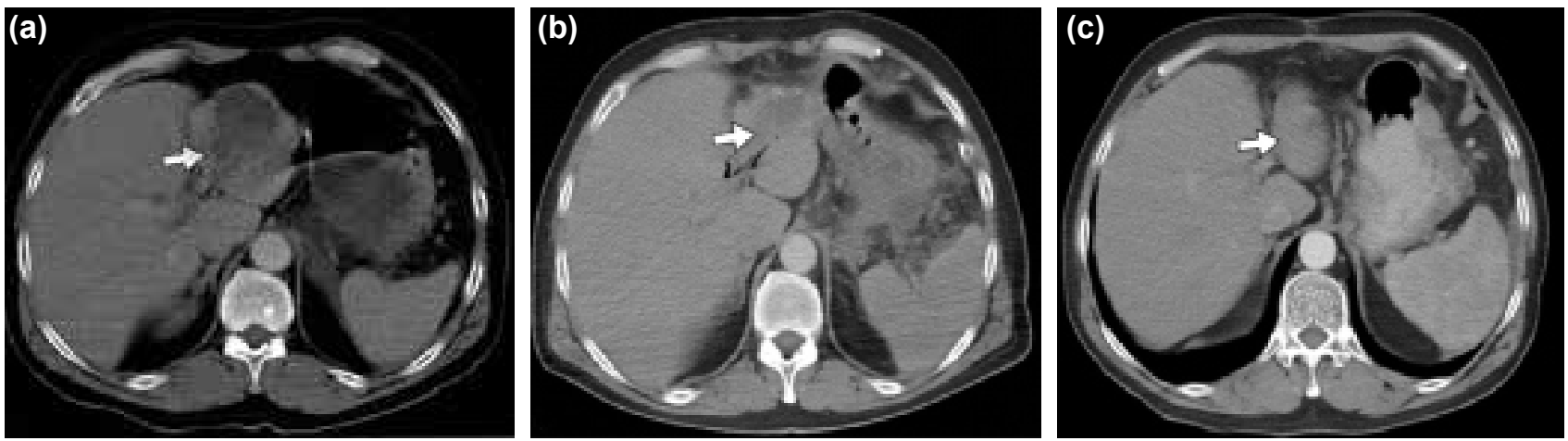

Figure 1. Complicated hydatid cyst in the liver. Intrabiliary rupture of cyst in left lobe (a). Drained cyst on seventh postoperative day (b). Drained cyst 6 months after surgery (c).
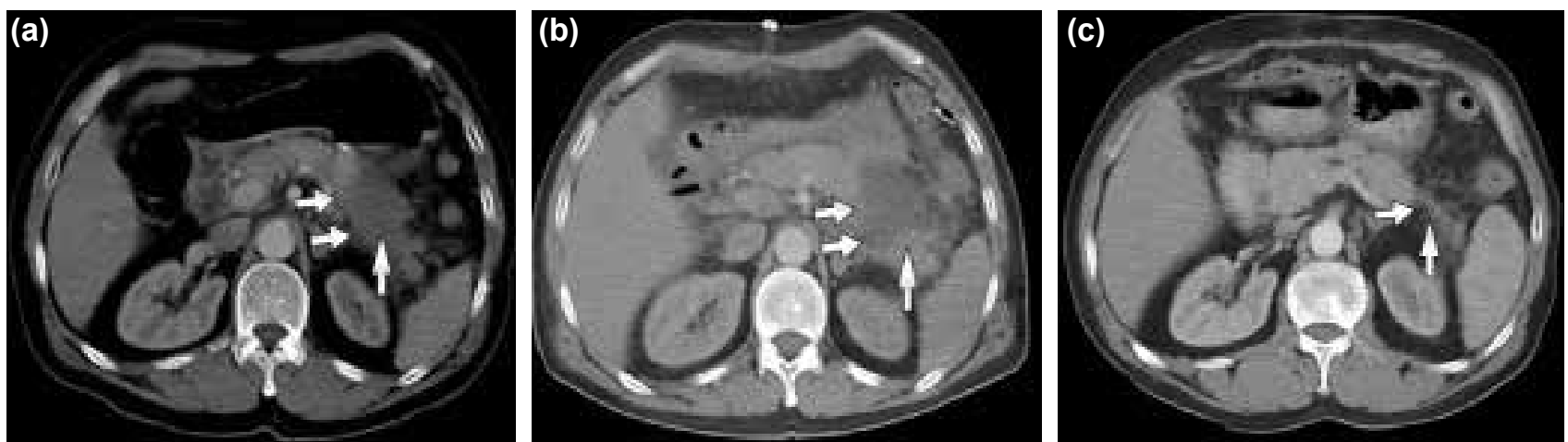

Figure 2. Necrotizing pancreatitis. Necrosis on tail of pancreas (a). Peripancreatic fluid collection around necrosis on seventh postoperative day (b). Pancreas 6 months after surgery (c).

performed to assess infected pancreatic necrosis; however, no additional surgical intervention was required for necrotizing pancreatitis.

Clinical and laboratory findings resolved rapidly. Only serum amylase level remained elevated for 2 weeks. CT scan showed peripancreatic fluid collection around necrosis on seventh postoperative day (Fig. 2b). T-tube was removed after 12 days, following evaluation with T-tube cholangiography. Patient was discharged uneventfully 2 weeks after surgery. Daily $15 \mathrm{mg} / \mathrm{kg}$ albendazole treatment was administered for 6-month period (cycle of 3 weeks with medication followed by I week without). There was no recurrent episode of pancreatitis during I year of follow-up.

\section{DISCUSSION}

Hydatid disease usually presents as liver cysts, and frequently produces no symptoms for many years until cyst exerts pressure on surrounding liver tissue. ${ }^{[1,2]}$ In $1 \%$ to $25 \%$ of cases, hydatid cyst ruptures into the biliary tree, causing biliary colic, obstructive jaundice, and cholangitis. ${ }^{[5]}$ Reports in the literature reveal that hydatid acute pancreatitis presents as edematous pancreatitis. ${ }^{[3,4]}$ Mechanical obstruction of papillary orifice by daughter cysts resulting in reflux of bile with hydatid material and increase in intrapancreatic pressure may be mechanism for pancreatitis. ${ }^{[2,6-10]}$ Our case supports this clinical entity.
Endoscopic sphincterotomy is safe and well-defined method to treat hydatid cysts with intrabiliary rupture and pancreatitis. ${ }^{[2,6-10]}$ Surgery following initial episode is common choice for most cases. Drainage of cyst, appropriate cavity management, and T-tube drainage of common bile duct to control bile leakage are principles of operation. ${ }^{[2]}$ In our case, difficult cannulation prevented endoscopic sphincterotomy. An emergency operation was performed to eliminate possible cause of necrotizing pancreatitis: mechanical obstruction of papillary orifice.

Conservative management is basis of treatment and results in success in most cases of acute pancreatitis. There is recognized increase in morbidity and mortality in infected versus sterile pancreatic necrosis. ${ }^{[1]}$ Infected pancreatic necrosis is primary indication for surgical intervention, and the goal of successful therapy is to identify patients who progress to infected necrosis. ${ }^{[11,12]}$ Intraoperative fine needle aspiration confirmed sterile necrosis in present patient. CT scan showed peripancreatic fluid collection around necrosis on seventh postoperative day, without expansion of necrosis and no additional surgery was performed for necrotizing pancreatitis. Hydatid necrotizing and edematous pancreatitis have similar progress. Recovery is quick and uneventful after elimination of mechanical obstruction on papillary orifice.

Conflict of interest: None declared. 


\section{REFERENCES}

1. Avgerinos ED, Pavlakis E, Stathoulopoulos A, Manoukas E, Skarpas G, Tsatsoulis $\mathrm{P}$. Clinical presentations and surgical management of liver hydatidosis: our 20 year experience. HPB (Oxford) 2006;8:189-93. Crossre.

2. Menteş A. Hydatid liver disease: a perspective in treatment. Dig Dis 1994;12:150-60. Crossret

3. Zeytunlu M, Coker A, Yüzer Y, Ersöz G, Aydin A, Tekeşin O, et al. Hydatid acute pancreatitis. Turk J Gastroenterol 2004;15:229-32.

4. Mestiri S, Salah HH, Achour H, Jerbi A, Belaid S. Acute pancreatitis, complication of hydatid cysts of the liver opening into the biliary tract. [Article in French] Chirurgie 1975;101:639-41. [Abstract]

5. Erzurumlu K, Dervisoglu A, Polat C, Senyurek G, Yetim I, Hokelek M. Intrabiliary rupture: an algorithm in the treatment of controversial complication of hepatic hydatidosis. World J Gastroenterol 2005;11:2472-6.

6. Cakır OO, Ataseven H, Demir A. Hydatid acute pancreatitis. Turkiye
Parazitol Derg 2012;36:251-3.

7. Katsinelos P, Chatzimavroudis G, Fasoulas K, Kamperis E, Katsinelos T, Terzoudis S, et al. Acute pancreatitis caused by impaction of hydatid membranes in the papilla of Vater: a case report. Cases J 2009;2:7374.

8. Aydin A, Ersöz G, Tekesin O, Mentes A. Hydatid acute pancreatitis: a rare complication of hydatid liver disease. Report of two cases. Eur J Gastroenterol Hepatol 1997;9:211-4. Crossre-

9. Ozaslan E, Bayraktar Y. Endoscopic therapy in the management of hepatobiliary hydatid disease. J Clin Gastroenterol 2002;35:160-74. Crossret

10. Dumas R, Le Gall P, Hastier P, Buckley MJ, Conio M, Delmont JP. The role of endoscopic retrograde cholangiopancreatography in the management of hepatic hydatid disease. Endoscopy 1999;31:242-7. Crossret

11. Fink D, Alverdy JC. Acute pancreatitis. In: Cameron JL, Cameron A, editors. Current surgical therapy. 10th ed. Philadelphia: Elsevier Saunders; 2011. pp. 383-8. Crossreet

12. Martin RF, Hein AR. Operative management of acute pancreatitis. Surg Clin North Am 2013;93:595-610. Crossre

\section{OLGU SUNUMU - ÖZET}

\section{Komplike kist hidatikte sıradışı bir tablo: Nekrotizan pankreatit}

\section{Dr. Hasan Ediz Sıkar, Dr. Levent Kaptanoğlu, Dr. Metin Kement}

Kartal Dr. Lütfi Kırdar Eğitim ve Araştırma Hastanesi, Genel Cerrahi Kliniği, İstanbul

Hidatik akut pankreatit nadir görülen ve her zaman akut ödematöz pankreatit olarak seyreden bir tablodur. Karaciğer kist hidatiğinin safra yollarına açılması ve papiller açıklığın hidatik membranlarla tıkanması olası mekanizmalardan biridir. Epigastrik ve sağ üst kadran ağrısı, bulantı, kusma şikayetiyle başvuran 49 yaşında erkek hastanın bilgisayarlı tomografi incelemesinde karaciğer sol lobunda $5 \times 5 \mathrm{~cm}$ ebatlarında kistin safra yollarına açılarak nekrotizan pankreatite yol açtığı görüldü. Endoskopik retrograd kolanjiyopankreatikografi denemesinin başarısız olması nedeniyle hastada kistotomi, koledok eksplorasyonu, T-Tüp drenaj ve omentoplasti operasyonu tercih edildi. Nekrotizan pankreatit için ilave girişim yapılmadı. Klinik ve laboratuvar bulguları hızla düzelen hastada bir yıllık takip süresinde tekrar pankreatit gelişimi saptanmadı. Hidatik ödematöz ve nekrotizan pankreatit benzer kliniğe sahiptir, papillada bulunan tıkanıklığın ortadan kaldırılmasıyla iyileşme süreci hızlı ve sorunsuz olmaktadır.

Anahtar sözcükler: Ekinokokkoz; pankreatit; safra fistülü.

Ulus Travma Acil Cerrahi Derg 2017;23(I):8I-83 doi: 10.5505/tjtes.2016.26820 